\title{
A study on the effect of Aldosterone antagonist on Nociception and anxiety in Swiss albino mice
}

\author{
Suresh.M ${ }^{1}$, Chandrasekar.M ${ }^{2}$, Nilesh N.Kate ${ }^{3}$, S.Qairunnisa ${ }^{1}$, Sanghishetti \\ Vijay Prasad $^{4} \&$ Ambareesha Kondam ${ }^{1}$ \\ ${ }^{1}$ Tutor in Department of Physiology, Meenakshi Medical College \& Research institute, \\ Kanchipuram, MAHER University \\ ${ }^{2}$ Professor in Department of Physiology, Meenakshi Medical College and Research institute, \\ Kanchipuram, MAHER University \\ ${ }^{3}$ Assistant Professor in Department of Physiology, Meenakshi Medical College \& Research institute, \\ Kanchipuram, MAHER University \\ ${ }^{4}$ Tutor in Dept of Pharmacology, Padmashri Dr. Vitthalrao Vikhe Patil Foundation's Medical College, \\ Ahmednagar, Maharashtra
}

\begin{abstract}
An aldosterone antagonist, used for the treatment of hypertension, edema, hyper-aldosteronism and also act as the antiinflammatory functions. Spironolactone is a steroid, easily available and marketed as a trade name aldactone. This drug is used for blocking aldosterone dependent sodium transport in the distal tubule of the kidney in order to reduce oedema and to treat essential hypertension and primary hyperaldosteronism. In this study aldosterone antagonist Spironolactone was administrated to find the effect of thermally induced pain, visceral pain and behavioral response in Swiss albino mice. The effects of spironolactone aldosterone antagonist, were examined on thermally-induced pain using the hot-plate and hot water tail immersion test $\left(53-54^{\circ} \mathrm{C}\right)$. The visceral nociception was observed by intra-peritoneal acetic acid injection and the behavioral responses in the mice were examined by using open field behavioral model test. In hot plate test and hot water tail immersion test spironolactone significantly $(0.01)$ reduces the pain threshold in dose dependent manner and increases the somatic pain, was as in visceral pain induced by acetic acid writhing spironolactone significantly $(0.003)$ increases the pain threshold and decreases the visceral pain. In behavioral study spironolactone decrease the ambulation, rearing and grooming and significantly (0.01) increases immobilization time and urination. Spironolactone increased somatic pain in hot plate test and hot water tail immersion test and decreases visceral pain in writhing test. The spironolactone also altered the behavioral response in mice, such as increased immobilization and decreased ambulation.
\end{abstract}

Keywords: Spironolactone, aldosterone antagonist, and Swiss albino mice.

\section{INTRODUCTION}

The aldosterone antagonist which is chemically related to the mineralocorticoid aldosterone is spironolactone. Spironolactone is a steroid, easily available in the market as aldactone. This drug is used for blocking aldosterone dependent sodium transport in the distal tubule of the kidney in order to reduce oedema and to treat essential hypertension and primary hyperaldosteronism (Conn and Hinerman, 1977). ${ }^{[5]}$ The Mineralocorticoid Receptors (MRs) are mainly localized in the

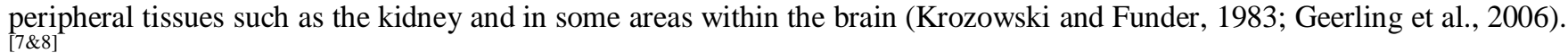

In addition to their prime physiologic role in the control of electrolyte homeostasis and blood pressure, studies have shown that Mineralocorticoid receptors (MRs) and Glucocorticoids receptors (GRs) are involved in the long-term corticosterone modulation of the anxiety response induced by restraint (Calvo and Volosin, 2001), while forebrain mineralocorticoid receptor over expression enhances memory, reduces anxiety and attenuates neuronal loss in cerebral ischemia (Lai et al., 2007). Excessive stimulation of MRs in the brain increases sympathetic excitation (Gomez-Sanchez, 1997). ${ }^{[9]}$ In the amygdala, MR-mediated mechanisms are likely to be involved in descending pathways onto lumbosacral spinal neurons that induce colorectal hypersensitivity to luminal distension (Qin et al., 2003). MR binds to glucocorticoids with a 10-fold higher affinity than GR, which are widely distributed in brain and periphery. Both GR and MR are involved in anxiety and cognitive function (de Kloet et al, 2005). ${ }^{[3]}$ 
The present study was designed to investigate for a possible pain modulating effect and behavioural response of aldosterone receptor blockade with spironolactone. In this study aldosterone antagonist Spironolactone was administrated to find the effect of thermally induced pain, visceral pain and behavioral response in swiss albino mice.

\section{MATERIALS AND METHODS}

The study was approved by Institutional Animal Ethics Committee. Healthy adult male Swiss albino mice weighing (20-25gms) were used for the study. Mice were housed under standardized conditions with free access to food and water ad libitum. Animal procedures were performed in accordance with the Ethics Committee.

\section{Hot plate test}

The test was performed using electrical hot plate maintained at a temperature of $55 \pm 1{ }^{\circ} \mathrm{C}$. The basal reaction time of all animals towards thermal heat was recorded. The animals which showed forepaw licking or jumping response within 6-8 secs were selected for the study. Different groups of mice ( $\mathrm{n}=2 /$ group) were given spironolactone $(10,40 \mathrm{or} 80 \mathrm{mg} / \mathrm{kg} / \mathrm{day}$, orally). Measurements were then taken $60 \mathrm{~min}$ after drug administration were individually exposed to the hot plate maintained at $55^{\circ} \mathrm{C}$. Latency to lick a hind paw or jump out of the apparatus was recorded and compared with control group. The time was noted for fore paw licking or jumping is/was taken as reaction time. A cut off period was taken as 15 secs to avoid damage to the paws.

\section{Hot water tail immersion test}

The hot water tail Immersion test unit serves to assess the tail flick reaction of mice. By holding, wrapping or placing the animal in a restrainer with the tail exposed. Then the tail is immersed into the water bath $\left(55-60^{\circ} \mathrm{C}\right)$ and time is noted by using stop watch. The timer is stopped when the animal reacts by flicking their tail and reaction time was noted.

\section{Acetic acid induced writhing test:}

Control group were administered with saline and the test group was given spironolactone $10,40 \mathrm{or} 80 \mathrm{mg} / \mathrm{kg}$, orally. Acetic acid $(0.6 \%)$ was administered intraperitoneally to all the groups at the dose of 10,40 and $80 \mathrm{mg} / \mathrm{kg}$ body weight 60 min after the administration of spironolactone. Drug effect was recorded by counting the number of writhes after the injection of acetic acid for a period of $10 \mathrm{~min}$.

\section{Behavioral study - Open-field test:}

Open field behavior study was done for control group. Then the spironolactone was administered (10,40 and 80 $\mathrm{mg} / \mathrm{kg}$ ) Exploratory behavior was assessed by placing animals individually into an open-field box marked off into 25 equal squares. A mouse is placed on one corner of the apparatus and is observed for 5 minutes. The parameters noted are a) Ambulation i.e., The number of times crossing the square with all four limbs, if peripheral squares it is peripheral ambulation, if it is central squares then it is central ambulation. b) Immobilization time c) Rearing d) Grooming e) Urination

\section{RESULTS}

All data were analyzed by using student's t-test, In hot plate test and tail immersion test spironolactone significantly $(\mathrm{p}<0.01)$ reduces the pain threshold in a dose dependent manner (table:1). In visceral pain, spironolactone significantly ( $\mathrm{p}<$ 0.01 ) increases the pain threshold (table:1). In behavioral study spironolactone decrease the ambulation, rearing and grooming and significantly $(\mathrm{p}<0.01)$ increases immobilization time and urination (table:2).

Table: 1 Thermal and Visceral nociception

\begin{tabular}{|c|c|c|c|c|}
\hline Test name & Dosage & Mean(sec) & S.D & P-value \\
\hline $\begin{array}{c}\text { Hot plate test } \\
\text { control: 10.33(sec) }\end{array}$ & $10 \mathrm{mg} / \mathrm{kg}$ & 9 & 0.89 & 0.08 \\
\cline { 2 - 5 } & $40 \mathrm{mg} / \mathrm{kg}$ & 8 & 0.89 & 0.01 \\
\cline { 2 - 5 } & $80 \mathrm{mg} / \mathrm{kg}$ & 7.33 & 0.52 & 0.001 \\
\hline $\begin{array}{c}\text { Hot water tail } \\
\text { Immersion test Control: } \mathbf{4 . 3}\end{array}$ & $10 \mathrm{mg} / \mathrm{kg}$ & 2.92 & 0.15 & 0.001 \\
\cline { 2 - 5 }$(\mathbf{s e c})$ & $40 \mathrm{mg} / \mathrm{kg}$ & 2.4 & 0.36 & 0.001 \\
\cline { 2 - 5 } & $80 \mathrm{mg} / \mathrm{kg}$ & 2.83 & 0.31 & 0.001 \\
\hline $\begin{array}{c}\text { Acetic acid writhing test } \\
\text { (no of times/ 10min): }\end{array}$ & $10 \mathrm{mg} / \mathrm{kg}$ & 19.42 & 0.93 & 0.001 \\
\cline { 2 - 5 } control : 23.83 & $40 \mathrm{mg} / \mathrm{kg}$ & 21.19 & 0.98 & 0.001 \\
\cline { 2 - 5 } & $80 \mathrm{mg} / \mathrm{kg}$ & 21 & 0.94 & 0.001 \\
\hline
\end{tabular}


Table: 2 Behavioral study - Open-field test

\begin{tabular}{|c|c|c|c|c|}
\hline Test name & Dosage & Mean & S.D & P-value \\
\hline \multirow{3}{*}{$\begin{array}{c}\text { Peripheral } \\
\text { ambulation } \\
\text { control : } 82.67\end{array}$} & $10 \mathrm{mg} / \mathrm{kg}$ & 76.33 & 9.91 & 0.195 \\
\hline & $40 \mathrm{mg} / \mathrm{kg}$ & 73.67 & 7.2 & 0.032 \\
\hline & $80 \mathrm{mg} / \mathrm{kg}$ & 67.33 & 8.82 & $0.004 *$ \\
\hline \multirow{3}{*}{$\begin{array}{c}\text { Central } \\
\text { ambulation } \\
\text { control : } 4.00\end{array}$} & $10 \mathrm{mg} / \mathrm{kg}$ & 3.5 & 3.08 & 0.767 \\
\hline & $40 \mathrm{mg} / \mathrm{kg}$ & 2.83 & 2.04 & 0.408 \\
\hline & $80 \mathrm{mg} / \mathrm{kg}$ & 1.5 & 1.38 & 0.064 \\
\hline \multirow{3}{*}{$\begin{array}{c}\text { Rearing } \\
\text { (no of times/5min) } \\
\text { control : } 12.83\end{array}$} & $10 \mathrm{mg} / \mathrm{kg}$ & 15.17 & 7.94 & 0.613 \\
\hline & $40 \mathrm{mg} / \mathrm{kg}$ & 8.17 & 3.92 & 0.209 \\
\hline & $80 \mathrm{mg} / \mathrm{kg}$ & 5.5 & 3.08 & $0.052 *$ \\
\hline \multirow{3}{*}{$\begin{array}{c}\text { Grooming } \\
\text { (no of times } / 5 \mathrm{~min} \text { ) } \\
\text { control : } 22.83\end{array}$} & $10 \mathrm{mg} / \mathrm{kg}$ & 18.33 & 8.31 & 0.469 \\
\hline & $40 \mathrm{mg} / \mathrm{kg}$ & 13.33 & 5.5 & 0.11 \\
\hline & $80 \mathrm{mg} / \mathrm{kg}$ & 10.20 & 5.98 & 0.109 \\
\hline \multirow{3}{*}{$\begin{array}{l}\text { Immobilization } \\
\text { (no of times/5min) } \\
\text { control : } 9.50\end{array}$} & $10 \mathrm{mg} / \mathrm{kg}$ & 11.5 & 3.56 & 0.514 \\
\hline & $40 \mathrm{mg} / \mathrm{kg}$ & 23.5 & 10.15 & $0.016^{*}$ \\
\hline & $80 \mathrm{mg} / \mathrm{kg}$ & 26.67 & 6.06 & $0.007 *$ \\
\hline \multirow{3}{*}{$\begin{array}{c}\text { Urination } \\
\text { (no of times } / 5 \mathrm{~min} \text { ) } \\
\text { control : } \mathbf{0 . 3 3}\end{array}$} & $10 \mathrm{mg} / \mathrm{kg}$ & 0.67 & 0.52 & 0.289 \\
\hline & $40 \mathrm{mg} / \mathrm{kg}$ & 1.5 & 1.05 & $0.034 *$ \\
\hline & $80 \mathrm{mg} / \mathrm{kg}$ & 2.33 & 1.03 & $0.001 *$ \\
\hline
\end{tabular}

\section{DISCUSSION}

Results of the present study provide the evidence of the administration of spironolactone have differing effects on acute nociceptive pain. Thus in models of tail immersion and hot plate in mice, which are measures of thermally-induced pain, the drug decreased nociceptive pain threshold. But in visceral pain increases nociceptive pain threshold by acetic acid injection into the peritoneal cavity, a widely used model for visceral pain. The effect of the oral administration of the drug on visceral pain responses, however, was not dose-dependent.

Spironolactone thus is likely to act at spinal and supraspinal sites to modulate pain responses. The presence of mineralocorticoid receptors in some areas within the brain such as the hippocampus and within the nucleus of the solitary tract (Krozowski and Funder, 1983)[7] have been demonstrated. Studies suggest that aldosterone, originating in the periphery and acting on brain MRs, Activates brain mitogen activated protein kinase (MAPK) pathways to produce sympathoexcitatory responses (Geerling etal., 2006)[8]. In contrast, central MR blockade has been shown to reduce sympathetic drive (Francis et al., 2001). [23] Significant changes in adrenal and blood aldosterone levels were seen 2.5 min after acute nociception (Belyakova and Mendzheritskii, 2006). ${ }^{[24]}$ Furthermore, in intact rats, the brain concentration of aldosterone reflected that in the plasma and aldosterone was consistently found in the brains of adrenalectomized rats, suggesting that the small amounts of aldosterone synthesized in the brain could provide a local ligand for autocrine or paracrine activation of the MR (Gomez- Sanchez et al., 2005). ${ }^{[9]}$

The effect of spironolactone on pain responses are not clear, but it has been shown that, aldosterone micro pellets implanted in amygdale led to increased visceromotor behavioral responses to colorectal distention. Thus MR-mediated mechanisms are likely to be involved in descending pathways into lumbosacral spinal neurons that induce colorectal hypersensitivity to luminal distention (Qin et al 2003). ${ }^{[10]}$ Aldosterone implants into the amygdale increased the number of abdominal muscle contractions in response to all levels of colorectal distension. MR mediated mechanisms thus induce 
visceral hypersensitivity via processes originating in the amygdala (Myers and Greenwood-Van Meerveld, 2010). ${ }^{[1]}$ Blockade of central MRs by spironolactone is therefore expected to reduce visceral pain responses. Spironolactone also possesses potent anti-inflammatory and immune modifying properties (Hansen et al., 2004). ${ }^{[12]}$ This could be relevant to its visceral pain inhibiting properties shown in the present study.

The model of inflammatory pain evoked by acetic acid injection into the peritoneal cavity involves the local release of prostaglandins in the peritoneal cavity (Berkenkopf and Weichman, 1988). ${ }^{[13]}$ GR and MR activation in the amygdala induced anxiety-like behavior and visceral hyperalgesia, Whereas only MR activation increased responsiveness to lower distension pressures and only GR was involved in enhanced cutaneous sensitivity. GR or MR activation is sufficient to induce anxiety and visceral hyperalgesia, MR is necessary for increased sensitivity to lower levels of visceral stimulation and GR is necessary for altered somatic sensation. ${ }^{[14]}$. GRs and MRs act as transcription factors and regulate the expression of many target genes. One known gene product of both GR and MR is CRF. ${ }^{[15,16]}$ The descending projections from the amygdala directly to brain stem structures such as the Periaqueductal gray (PAG) may be important as these pathways play a prominent role in pain modulation. ${ }^{(17,18,19)}$ Although the PAG provides direct opioid modulation of spinal nociception, the amygdala also influences the activity of other brain stem nuclei including the raphe nuclei and LC that can alter the excitability of both supraspinal and spinal circuits. ${ }^{(17,18,20)}$

The descending projections from the CeA to the brain stem that modulate sensory processing in the spinal cord produce neuronal hyperexcitability. Descending modulation of spinal nociceptive processing may be a mechanism for the GR and MR divergence seen in the present study since the effects of Corticosterone on spinal neuronal excitability were blocked by placing the MR antagonist spironolactone on the amygdala. GR and MR are important for the regulation of visceral sensitivity and anxiety-like behavior, although amygdaloidal GR and MR are both involved in anxiety-like behavior; the receptors have divergent effects on visceral and somatic sensation.

\section{CONCLUSION}

Spironolactone increased pain behavior in a dose-dependent manner in models of thermal (hot plate and tail immersion test) but decreased inflammatory visceral pain in writhing test due to intraperitoneal acetic acid. The spironolactone also altered the behavioral response in mice, such as increased immobilization and decreased ambulation. The Spironolactone has effects on pain modulation and behavioral response other than the maintenance of blood pressure and anti inflammatory functions.

\section{REFERENCES}

[1]. Caminos - torres ,R., Ma,L., and Snyder. Testosterone- induced inhibition of the LH and FSH responses to gonadotropin- releasing hormone occurs slowly. J. Clin. Endocrinol. Metab., 1977. 44; 1142-1153.

[2]. Fan YS, Eddy RL, Byers MG, Haley LL,Henry WM, Nowak NJ, Shows TB (1989). "The human mineralocorticoid receptor gene (MLR) is located on chromosome 4 at q31.2".Cytogenet. Cell Genet. 52 (1-2): 83-4. doi:10.1159/000132846. PMID 2558856.

[3]. De Kloet ER, Joels M, Holsboer F (2005). Stress and the brain: from adaptation to disease. Nat Rev Neurosci 6: 463-475.

[4]. Dib N, Oberti F, Cales P. Current management of the complications of portal hypertension: variceal bleeding and ascites. Can Med Assoc J 2006;174:1433-43.

[5]. Conn JW, Hinerman DL. Spironolactoneinduced inhibition of aldosterone biosynthesis in primary aldosteronism: morphological and functional studies. Metabolism1977; 26:1293-307.

[6]. Fuller PJ, Young MJ (2005). "Mechanisms of mineralocorticoid action". Hypertension 46(6): 1227-35. doi:10.1161/01.HYP.0000193502.77417.17. PMID

[7]. Krozowski ZS, Funder JW. Renal mineralocorticoid receptors and hippocampal corticosterone-binding species have identical intrinsic steroid specificity. Proc Natl Acad Sci U S A 1983;80: 6056-60.

[8]. Geerling JC, Kawata M, Loewy AD. Aldosterone-sensitive neurons in the rat central nervous system. J Comp Neurol 2006; 494: 515-27.

[9]. Gomez-Sanchez EP, Ahmad N, Gomez-Sanchez CE. Is aldosterone synthesized within the rat brain Am J Physiol Endocrinol Metab 2005; 288: E342-6.

[10]. Qin C, Greenwood-Van Meerveld B, Foreman RD. Visceromotor and spinal neuronal responses to colorectal distension in rats with aldosterone onto the amygdala. J Neurophysiol 2003; 90:2-11. 
[11]. Myers B, Greenwood-Van Meerveld B. Divergent effects of amygdala glucocorticoid and mineralocorticoid receptors in the regulation of visceral and somatic pain. Am J Physiol Gastrointest Liver Physiol 2010;298:G295-303.

[12]. Hansen PR, Rieneck K, Bendtzen K. Spironolactone inhibits production of pro inflammatory cytokines by human mononuclear cells. Immunol Lett 2004; 91: 87-91.

[13]. Berkenkopf JW, Weichman BM. Production of prostacyclin in mice following intraperitoneal injection of acetic acid, phenylbenzoquinone and zymosan: its role in the writhing response. Prostaglandins 1988;36:693-709.

[14]. Grossmann C, Scholz T, Rochel M, Bumke-Vogt C, Oelkers W, Pfeiffer AFH, Diederich S, Bahr V. Transactivation via the human glucocorticoid and mineralocorticoid receptor by therapeutically used steroids in CV-1 cells: a comparison of their glucocorticoid and mineralocorticoid properties. Eur J Endocrinol 151: $397-$ 406, 2004.

[15]. Schulkin J, Gold PW, McEwen BS. Induction of corticotropin-releasing hormone gene expression by glucocorticoids: implication for understanding the states of fear and anxiety and allostatic load. Psychoneuroendocrinology 23: 219-243, 1998.

[16]. Watts AG, Sanchez-Watts G. Region-specific regulation of neuropeptide mRNAs in rat limbic forebrain neurones by aldosterone and corticosterone J Physiol 484: 721-736, 1995.

[17]. Behbehani MM. Functional characteristics of the midbrain periaqueductal gray. Prog Neurobiol 46: 575-605, 1995.

[18]. Jones MP, Dilley JB, Drossman D, Crowell MD. Brain-gut connections in functional GI disorders: anatomic and physiologic relationships. Neurogastroenterol Motil 18: 91-103, 2006.

[19]. Rizvi TA, Ennis M, Behbehani MM, Shipley MT. Connections between the central nucleus of the amygdala and the midbrain periaqueductal gray: topography and reciprocity. J Comp Neurol 303: 121-131, 1991.

[20]. Veening JG, Swanson LW, Sawchenko PE. The organization of projections from the central nucleus of the amygdala to brainstem sites involved in central autonomic regulation: a combined retrograde transportimmunohistochemical study. Brain Res 303: 337-357, 1984.

[21]. Venkova K, Foreman RD, Greenwood-Van Meerveld B. Mineralocorticoid and glucocorticoid receptors in the amygdala regulate distinct responses to colorectal distension. Neuropharmacology 56: 514-521,2009.

[22]. Sinclair JG, Main CD, Lo GF. Spinal vs. supraspinal actions of morphine on the rat tail-flick reflex. Pain 1988; 33: 357-62.

[23]. Francis J, Weiss RM, Wei SG, Johnson AK, Beltz TG, Zimmerman K, Felder RB. Central mineralocorticoid receptor blockade improves volume regulation and reduces sympathetic drive in heart failure. Am J Physiol Heart Circ Physiol 2001; 281: H2241-51.

[24]. Belyakova EI, Mendzheritskii AM. Adrenocortical and thyroid systems of rats during the initial period of nociceptive influences. Neurosci Behav Physiol 2006; 36: 561-4.

[25]. Davis M. Neurobiology of fear responses: the role of the amygdala. JNeuropsychiatry Clin Neurosci 9: 382402, 1997. 